\title{
THE EFFECT OF ROOT CANAL TAPER ON THE REMOVAL OF SMEAR LAYER USING DIFFERENT IRRIGATING SOLUTIONS: A SCANNING ELECTRON MICROSCOPE STUDY
}

\author{
Atul Jain ${ }^{1}$, Sonal Sinha ${ }^{2}$, Rachana Bahuguna ${ }^{3}$, Neeraj Kumar ${ }^{4}$, Raju Chauhan ${ }^{5}$ \\ ${ }^{1}$ Professor \& Head, Department of Conservative Dentistry \& Endodontics, Saraswati Dental College \& Hospital, Uttar Pradesh, India \\ ${ }^{2}$ PG Student, Department of Conservative Dentistry \& Endodontics, Saraswati Dental College \& Hospital, Uttar Pradesh, India \\ ${ }^{3}$ Professor \& Head, Department of Pedodontics \& Preventive Dentistry, Saraswati Dental College \& Hospital, Uttar Pradesh, India \\ ${ }^{4}$ Reader, Department of Conservative Dentistry \& Endodontics, Saraswati Dental College \& Hospital, Uttar Pradesh, India \\ ${ }^{5}$ Reader, Department of Conservative Dentistry \& Endodontics, Saraswati Dental College \& Hospital, Uttar Pradesh, India
}

\begin{abstract}
\begin{tabular}{l|l|l}
\hline &
\end{tabular}
ABSTRACT

Aim: This study was carried out to evaluate the combined effect of taper and different irrigating agents on the cleanliness of root canal. Materials \&Methods: 45 extracted mandibular premolars were divided into three groups, according to the taper produced, $2 \%, 4 \%$ and $6 \%$ with Hero Shaper files respectively, which were further divided into subgroups, according to the irrigation regime followed. The teeth were split and subjected to SEM analysis. Results: The results showed that the canals prepared to a taper of $6 \%$ and irrigated with $5.2 \% \mathrm{NaOCl}$ and $25 \%$ Citric acid had less debris and smear layer, which was statistically significant. Conclusion: It was concluded that a taper of $6 \%$ facilitates irrigant delivery in the canal and $25 \%$ Citric acid is more potent demineralising agent than $17 \%$ EDTA.
\end{abstract}

Key Words: 25\% Citric acid, 17\% EDTA, 5.2\% NaOCl, Scanning Electron Microscope.

\section{INTRODUCTION}

Endodontic therapy has been compared to a chain, wherein the chain is only as strong as each individual link for successful root canal therapy. Cleaning and shaping of the root canal therapy is considered as a decisive link because shaping determines the efficacy of subsequent procedures. It includes mechanical debridement and the creation of space for the delivery of medicaments. ${ }^{1}$

The mechanical instrumentation of the root canal creates an irregular layer of debris known as the smear layer, which is formed on the dentinal walls. Smear layer containing bacteria or bacterial products might provide a reservoir of irritants. ${ }^{1}$ Thus complete removal of the smear layer

Corresponding Author:

Atul Jain

E-mail:

jaindratul@yahoo.co.in Received: $21^{\text {st }}$ Sept. 2014 Accepted: $17^{\text {th }}$ Dec. 2014 Online: $23^{\text {rd }}$ Jan. 2015 obturation material to the root canal walls. ${ }^{1}$ The aim of endodontic treatment is to control the microbial factor along with the removal of smear layer and debris. This objective is achieved by combining instrument based preparation (manual or mechanical) with irrigating solutions. However, factors like technique of instrumentation whether manual or rotary, ${ }^{1}$ degree of taper ${ }^{1}$ and the choice of irrigating agents $^{2}$ are still debatable. Numerous studies comparing the rotary with manual instrumentation have found the former to be superior in their ability to remove smear layer. Unfortunately few studies have been published investigating root canal cleanliness keeping in consideration all the above mentioned factors. Thus this study was taken up to evaluate the role of taper of the endodontic instruments along with different irrigating regimes. 


\section{MATERIALS AND METHODS}

This in vitro evaluation of the comparison of Rotary files with different tapers, in the removal of smear layer and debris from the root canal walls was carried out in the Post-Graduate Department of Conservative Dentistry and Endodontics, Saraswati Dental College and Hospital, Lucknow and in the Scanning Electron Microscope Department of Birbal Sahni Institute of Paleobotany, Lucknow.

45 freshly extracted permanent single, straight rooted, mandibular premolars were collected from the Department of Oral and Maxillofacial Surgery. The collected teeth were extracted for orthodontic reasons, which kept the age group constant. The inclusion criteria for the selected teeth were :

\section{1) Intact tooth structure.}

2) Permanent teeth with fully developed root.

3) Presence of a single root and canal.

4) Teeth with mature apex.

The exclusion criteria were:

1) Any developmental anomaly.

2) Resorptive defect.

3) Calcified canals.

4) Fracture or craze lines

5) Endodontic treatment.

6) Restoration involving the anatomic root.

Teeth were divided into different groups and subgroups as described in Table 1. Teeth were decoronated using a diamond disc mounted in a straight hand piece with a micromotor (NSK, Japan) at a distance of $10 \mathrm{~mm}$ from the apex, which was measured with the help of Vernier Callipers(Mitutoyo, Japan) (Figure 1). They were further divided into three groups and subgroups according to the taper produced and the irrigation regime used (Table 1). Patency of the canal

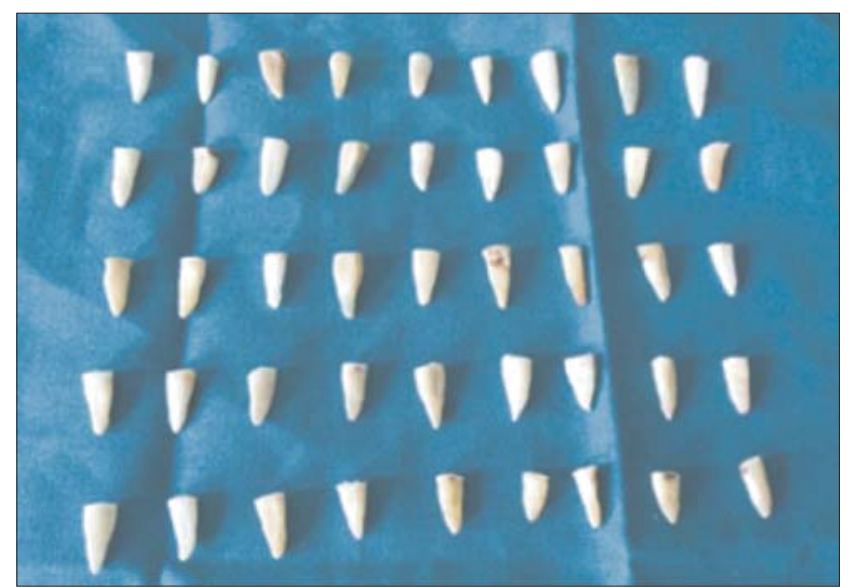

Figure 1 : Teeth Sample

was established using a No. $10 \mathrm{~K}$ - file and working length was confirmed by taking an intraoral periapical radiograph. Hero Shaper rotary system (Micro Mega, France) was used following the conventional principles of crown down technique. The apical preparation was maintained at No. 30 and providing 2\%, 4\% \& 6\% taper respectively at $450 \mathrm{rpm}$ and torque of $0.8 \mathrm{Ncm} .5 .2 \%$ Sodium hypochlorite (Novo Dental Products, Mumbai, India) was used for irrigation during biomechanical preparation.17\% EDTA (Amdent, India) and 25\% Citric Acid (Fischer Scientific, Mumbai, India) were used as the final irrigant and used in the subgroups, as mentioned in Table 1. The volume and duration of each irrigant used was kept constant at $5 \mathrm{ml}$ and 30 seconds respectively. For irrigation, 27 gauge side vented needle (Omega Inc.) was used. Final rinse was done with saline in order to eliminate the residual effect of any chemical used. After the completion of chemomechanical preparation, teeth were split longitudinally and subjected to Scanning Electron Microscope (EDAX LEO 430) analysis (Figure 2).

Table 1

\begin{tabular}{|c|c|c|c|c|c|c|c|c|}
\hline \multirow{2}{*}{\multicolumn{2}{|c|}{ Group }} & \multirow[t]{2}{*}{$\begin{array}{c}\text { Total No. of } \\
\text { samples }(n=45)\end{array}$} & \multirow{2}{*}{$\begin{array}{c}\text { Total No. } \\
\text { of obser- } \\
\text { vations } \\
(n=180)\end{array}$} & \multirow[t]{2}{*}{ Level } & \multirow{2}{*}{$\begin{array}{c}\begin{array}{c}\text { No. of } \\
\text { obser- }\end{array} \\
\text { vations } \\
(n=180)\end{array}$} & \multicolumn{3}{|c|}{$\begin{array}{c}\text { Subgroup } \\
\text { (Irrigating Solution used) }\end{array}$} \\
\hline & & & & & & $\begin{array}{c}\text { (a) } \\
\text { Saline }\end{array}$ & $\begin{array}{c}\text { (b) } \\
\text { Citric acid } \\
+\mathrm{NaOCl}\end{array}$ & $\begin{array}{c}\text { (c) } \\
\text { EDTA + } \\
\text { NaOCl }\end{array}$ \\
\hline \multirow{3}{*}{ I } & \multirow{3}{*}{$\begin{array}{l}\text { Hero Shaper } .02 \\
\text { taper }(2 \%)\end{array}$} & \multirow{3}{*}{15} & \multirow{3}{*}{45} & Coronal & 15 & \multirow{3}{*}{5} & \multirow{3}{*}{5} & \multirow{3}{*}{5} \\
\hline & & & & Middle & 15 & & & \\
\hline & & & & Apical & 15 & & & \\
\hline \multirow[t]{3}{*}{ II } & \multirow{3}{*}{$\begin{array}{c}\text { Hero Shaper .04 } \\
\text { taper }(4 \%)\end{array}$} & \multirow[t]{3}{*}{15} & \multirow[t]{3}{*}{45} & Coronal & 15 & \multirow[t]{3}{*}{5} & \multirow[t]{3}{*}{5} & \multirow[t]{3}{*}{5} \\
\hline & & & & Middle & 15 & & & \\
\hline & & & & Apical & 15 & & & \\
\hline \multirow[t]{3}{*}{ III } & \multirow{3}{*}{$\begin{array}{l}\text { Hero Shaper .06 } \\
\text { taper }(6 \%)\end{array}$} & \multirow[t]{3}{*}{15} & \multirow[t]{3}{*}{45} & Coronal & 15 & \multirow[t]{3}{*}{5} & \multirow[t]{3}{*}{5} & \multirow[t]{3}{*}{5} \\
\hline & & & & Middle & 15 & & & \\
\hline & & & & Apical & 15 & & & \\
\hline
\end{tabular}




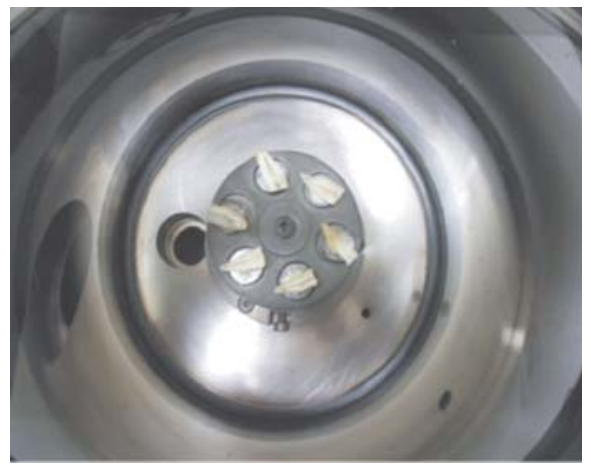

Figure 2 : Teeth Samples Mounted For Gold Sputtering

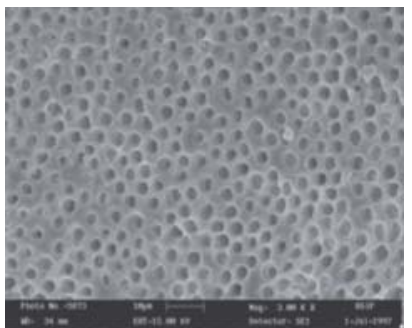

Coronal

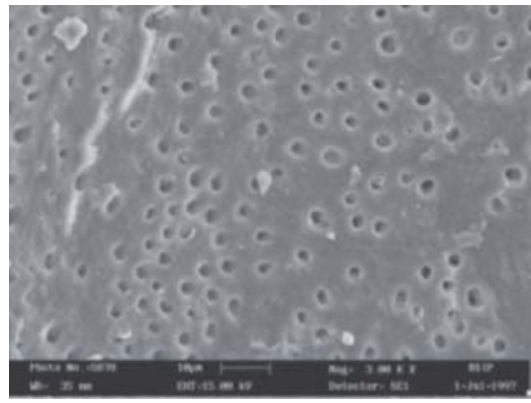

Apical

Figure $3: 6 \%$ Taper $+5.2 \% \mathrm{NaOCl}+25 \%$ Citric Acid
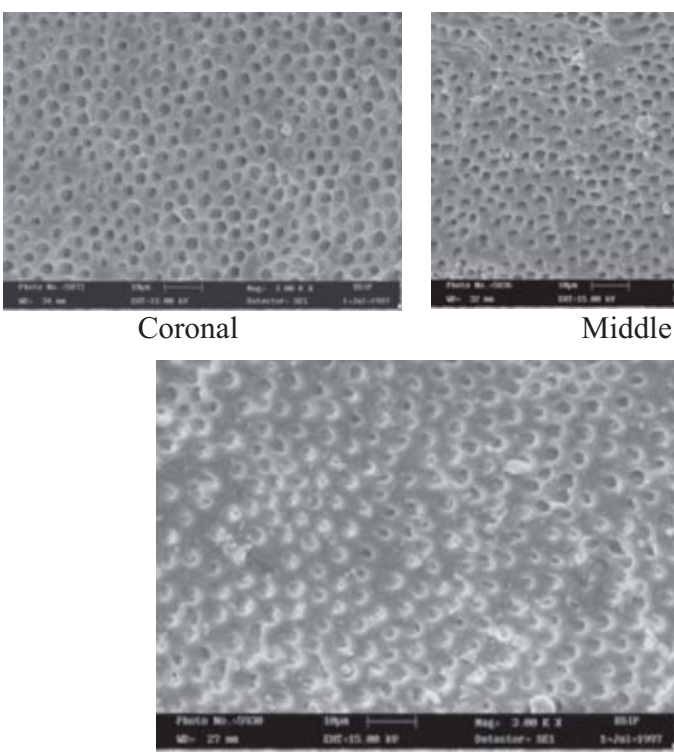

Apical

Figure $4: 6 \%$ Taper $+5.2 \% \mathrm{NaOCl}+17 \%$ EDTA
Images were taken of each sample at the Coronal, Middle and Apical thirds at $3000 \mathrm{X}$ magnification (Figure $3 \& 4$ ).

The images were examined in a blind manner by two investigators, who belonged to dental fraternity but were uninvolved in the present study. They individually rated the presence of debris / smear layer, assisigning a score between 1 to 4 , as described in Table 2. The scores for all images were recorded in tabular form by both observers and the data was subjected to statistical analysis.

Table 2 : Scoring Pattern

\begin{tabular}{|l|l|}
\hline Score 1 & $\begin{array}{l}\text { Presence of debris / smear layer that cover } \\
0-25 \% \text { of the surface examined }\end{array}$ \\
\hline Score 2 & $\begin{array}{l}\text { Presence of debris / smear layer that covers } \\
25 \%-50 \% \text { of the surface examined }\end{array}$ \\
\hline Score 3 & $\begin{array}{l}\text { Presence of debris/smear layer that covers } \\
50 \% \text { to } 75 \% \text { of the surface examined }\end{array}$ \\
\hline Score 4 & $\begin{array}{l}\text { Presence of debris / smear layer that covers } \\
75 \%-100 \% \text { of the surface examined }\end{array}$ \\
\hline
\end{tabular}

\section{RESULTS}

Evaluation of mean scores in different groups (irrespective of location and irrigant used) revealed mean scores to be maximum in Group I $(2.51 \pm 0.944)$
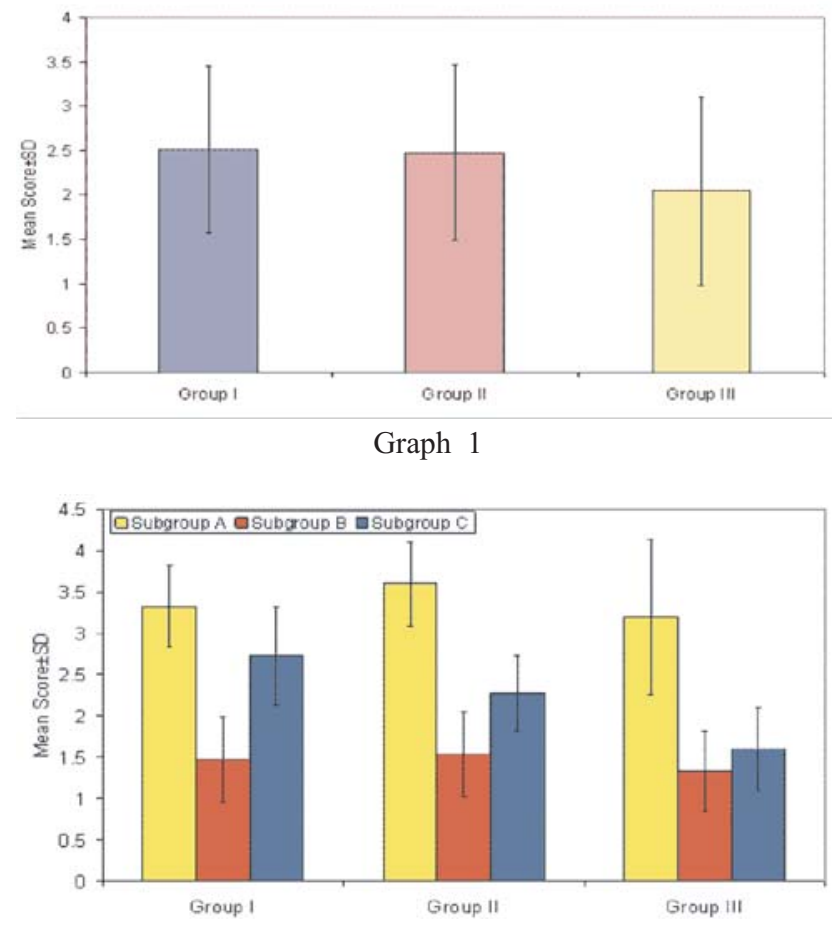

Graph 2 
Table 3 : Intergroup Comparison of Mean Scores in different groups irrespective of location and irrigating solution used

\begin{tabular}{|c|c|c|c|c|}
\hline Group & $\mathrm{N}$ & Mean & Std. Deviation & Median \\
\hline I & 45 & 2.51 & 0.944 & 3.00 \\
\hline II & 45 & 2.47 & 0.991 & 2.00 \\
\hline III & 45 & 2.04 & 1.065 & 2.00 \\
\hline Total & 135 & 2.34 & 1.016 & 2.00 \\
\hline
\end{tabular}

and minimum in Group III (2.04 \pm 1.065$)$ as described in Table 3 and Graph 1. Evaluation of intergroup difference using non-parametric analysis of variance (Kruskall Wallis test) revealed significant intergroup differences $(p<0.001)$. Overall, group wise, location wise and for all groups independently at all the locations, mean scores in subgroup II were minimum while that in subgroup I were maximum as described in Table 4 and Graph 2. All the comparisons showed significant inter subgroup differences $(\mathrm{p}<0.05)$. For all the groups, Subgroup A had maximum mean value while subgroup $B$ had minimum mean value. For all the groups, inter subgroup differences were significant statistically as described in Table 4 and Graph 2. From the readings of Table 5 it can be inferred that the coronal third of the canals was the cleanest (statistically significant) in comparison to the middle and apical third irrespective of the irrigation regime and taper.

\section{DISCUSSION}

To evaluate the effect of root canal taper in the removal of smear layer using different irrigating agents, the Hero Shapers were used as the representative system, since it is one of the most widely used rotary file systems, for root canal preparation. Hero Shaper system has produced significantly cleaner canal walls compared to the Hand Protaper system, $\mathrm{RaCe}$ and Rotary Protaper system. ${ }^{7,8}$ This finding may be due to the greater cutting efficiency of the Hero Shaper system which in turn may be due to the triple helix cross section of the Hero Shaper instruments which includes three cutting edges, each with a positive rake angle. Hero Shaper has been found to be highly effective in terms of cleaning curved canals due to its high flexibility. It is available in different tapers of $2 \%$, $4 \%$ and $6 \%$ thus permitting preparation of a wide range of canals.

Mandibular premolars were taken up for this study, since they are easier to split because of their thick

Table 4 : Comparison of Mean Scores with different irrigating solutions

\begin{tabular}{|c|c|c|c|c|}
\hline Subgroup & $\mathbf{N}$ & Mean & Std. Deviation & Median \\
\hline \multicolumn{5}{|c|}{ 2\% Hero Shaper } \\
\hline Saline & 15 & 3.33 & 0.488 & 3.00 \\
\hline Citric acid + Нypo & 15 & 1.47 & 0.516 & 1.00 \\
\hline EDTA + Hypo & 15 & 2.73 & 0.594 & 3.00 \\
\hline Total & 45 & 2.51 & 0.944 & 3.00 \\
\hline \multicolumn{5}{|c|}{$\chi^{2}=31.286 ; \mathrm{p}<0.001$ (Kruskall Wallis test) $(\mathrm{S})$} \\
\hline \multicolumn{5}{|c|}{ 4\% Hero Shaper } \\
\hline Saline & 15 & 3.60 & 0.507 & 4.00 \\
\hline Citric acid + Hypo & 15 & 1.53 & 0.516 & 2.00 \\
\hline EDTA + Hypo & 15 & 2.27 & 0.458 & 2.00 \\
\hline Total & 45 & 2.47 & 0.991 & 2.00 \\
\hline \multicolumn{5}{|c|}{$\chi 2=33.898 ; \mathrm{p}<0.002($ Kruskall Wallis test) $(\mathrm{S})$} \\
\hline \multicolumn{5}{|c|}{$6 \%$ Hero Shaper } \\
\hline Saline & 15 & 3.20 & 0.941 & 4.00 \\
\hline Citric acid + Hypo & 15 & 1.33 & 0.488 & 1.00 \\
\hline EDTA + Нypo & 15 & 1.60 & 0.507 & 2.00 \\
\hline Total & 45 & 2.04 & 1.065 & 2.00 \\
\hline \multicolumn{5}{|c|}{$\chi^{2}=25.013 ; \mathrm{p}<0.001$ (Kruskall Wallis test) $(\mathrm{S})$} \\
\hline
\end{tabular}


Table 5 : Location wise comparison of the groups in different irrigation regimes

\begin{tabular}{|c|c|c|c|c|c|}
\hline Group & Total $(n=45$ each $)$ & $\begin{array}{c}\text { Saline }(n=15 \\
\text { each })\end{array}$ & $\begin{array}{c}\text { Citric acid ( } n=15 \\
\text { each) }\end{array}$ & $\begin{array}{c}\text { EDTA+ Hypo } \\
(n=15 \text { each })\end{array}$ & $\begin{array}{l}p " \text { value (Within } \\
\text { group diff. } \\
\text { solutions) }\end{array}$ \\
\hline \multicolumn{6}{|c|}{ All Locations } \\
\hline I & $2.51 \pm 0.944$ & $3.33 \pm 0.488$ & $1.47 \pm 0.516$ & $2.73 \pm 0.594$ & $<0.001(\mathrm{~S})$ \\
\hline II & $2.47 \pm 0.991$ & $3.60 \pm 0.507$ & $1.53 \pm 0.516$ & $2.27 \pm 0.458$ & $0.002(\mathrm{~S})$ \\
\hline III & $2.04 \pm 1.065$ & $3.20 \pm 0.941$ & $1.33 \pm 0.488$ & $1.60 \pm 0.507$ & $<0.001(\mathrm{~S})$ \\
\hline "p" value & $<0.001(\mathrm{~S})$ & 0.376 (NS) & 0.540 (NS) & $<0.001(\mathrm{~S})$ & \\
\hline \multicolumn{6}{|c|}{ Normal Saline } \\
\hline & $\begin{array}{l}\text { All locations } \\
(n=15 \text { each) }\end{array}$ & $\begin{array}{l}\text { Coronal } \\
n=5 \text { each }\end{array}$ & $\begin{array}{c}\text { Middle } \\
\text { n=5 each }\end{array}$ & $\begin{array}{c}\text { Apical } \\
n=5 \text { each }\end{array}$ & $\begin{array}{l}\text { "p" value (Within } \\
\text { group diff. } \\
\text { locations) }\end{array}$ \\
\hline I & $3.33 \pm 0.488$ & $3.00 \pm 0.000$ & $3.00 \pm 0.000$ & $4.00 \pm 0.000$ & 0.001 \\
\hline II & $3.60 \pm 0.507$ & $3.00 \pm 0.000$ & $3.80 \pm 0.447$ & $4.00 \pm 0.000$ & 0.001 \\
\hline III & $3.20 \pm 0.941$ & $2.00 \pm 0.000$ & $3.60 \pm 0.548$ & $4.00 \pm 0.000$ & 0.001 \\
\hline "p" value & $0.376(\mathrm{NS})$ & $0.001(\mathrm{~S})$ & $0.039(\mathrm{~S})$ & $1.000(\mathrm{NS})$ & \\
\hline \multicolumn{6}{|c|}{ Citric Acid } \\
\hline & $\begin{array}{l}\text { All locations } \\
(n=15 \text { each) }\end{array}$ & $\begin{array}{l}\text { Coronal } \\
n=5 \text { each }\end{array}$ & $\begin{array}{c}\text { Middle } \\
\mathrm{n}=5 \text { each }\end{array}$ & $\begin{array}{c}\text { Apical } \\
n=5 \text { each }\end{array}$ & $\begin{array}{l}\text { "p" value (Within } \\
\text { group diff. } \\
\text { locations) }\end{array}$ \\
\hline I & $1.47 \pm 0.516$ & $1.00 \pm 0.000$ & $1.40 \pm 0.548$ & $2.00 \pm 0.000$ & 0.001 \\
\hline II & $1.53 \pm 0.516$ & $1.20 \pm 0.447$ & $1.40 \pm 0.548$ & $2.00 \pm 0.000$ & 0.001 \\
\hline III & $1.33 \pm 0.488$ & $1.00 \pm 0.000$ & $1.20 \pm 0.447$ & $1.80 \pm 0.447$ & 0.001 \\
\hline "p" value & $0.540(\mathrm{NS})$ & $0.368(\mathrm{NS})$ & $0.756(\mathrm{NS})$ & $0.368(\mathrm{NS})$ & \\
\hline \multicolumn{6}{|c|}{ EDTA } \\
\hline & $\begin{array}{l}\text { All locations } \\
(n=15 \text { each) }\end{array}$ & $\begin{array}{c}\text { Coronal } \\
n=5 \text { each }\end{array}$ & $\begin{array}{c}\text { Middle } \\
\text { n=5 each }\end{array}$ & $\begin{array}{c}\text { Apical } \\
n=5 \text { each }\end{array}$ & $\begin{array}{l}\text { "p" value (Within } \\
\text { group diff. } \\
\text { locations) }\end{array}$ \\
\hline I & $2.73 \pm 0.594$ & $2.00 \pm .000$ & $3.00 \pm .000$ & $3.20 \pm .447$ & 0.001 \\
\hline II & $2.27 \pm 0.458$ & $2.00 \pm .000$ & $2.00 \pm .000$ & $2.80 \pm .447$ & 0.001 \\
\hline III & $1.60 \pm 0.507$ & $1.00 \pm .000$ & $1.80 \pm .447$ & $2.00 \pm .000$ & 0.001 \\
\hline "p" value & $<0.001(\mathrm{~S})$ & $0.001(\mathrm{~S})$ & $0.002(\mathrm{~S})$ & $0.005(\mathrm{~S})$ & \\
\hline
\end{tabular}

roots. Since the possibility of root canal bifurcation is quite high in this group of teeth, premolars with only one canal were chosen in this study, after confirming radiographically.

To evaluate root canal cleanliness, removal of smear layer was considered as the base line criteria. During chemomechanical preparation of a root canal, the necrotic pulp tissue, microorganisms and dentinal shavings adhere to the naturally occurring smear layer present on the canal wall, rendering it resistant to removal. Once these smear plugs are removed successfully, the canal is freed of debris produced during the preparation. Hence evaluation of the removal of smear layer to assess root canal cleanliness is justified. The scanning electron microscope (SEM) was used in this study for evaluating the removal of smear layer. SEM uses a focused beam of high- energy electrons to generate a variety of signals at the surface of solid specimens. The signals derived from electronsample interactions reveal information about the sample including external morphology (texture), chemical composition, and crystalline structure and orientation of materials making up the sample, thus making scanning electron microscopy one of the most widely used technologies today, for analysis of smear layer. 
In this study $6 \%$ taper was found to produce the cleanest canals, irrespective of the irrigation regime and the location. This finding is in keeping with the results of Wandelt $(1965)^{9}$ Lee et al (2004) ${ }^{10}$ and Van Der Sluies et al (2005) ${ }^{11}$ who in different studies found that an increase in taper led to better debridement of the canal. Usman et $\mathrm{al}^{12}$ also reported better canal cleanliness with higher taper GT files in comparison to less taper. Increased taper facilitates more dentin removal from the canal walls and provides greater base diameter to the cone like preparation to the root canal leading to better penetration of the irrigants, where they can express their cleaning efficacy; thus producing a cleaner root canal. ${ }^{5,13,14}$

Amongst the irrigants evaluated in this study, combination of $5.25 \%$ of $\mathrm{NaOCl}$ and $25 \%$ citric acid (Figure 3) produced significantly cleaner canals than $5.25 \% \mathrm{NaOCl}+17 \%$ EDTA (Figure 4) and saline, irrespective of the final taper and location.

Citric Acid is a potent chelating agent used for the removal of smear layer. Chemically it is a weak organic acid and a chelating agent with properties comparable to EDTA and Ultrasonics. ${ }^{15}$ Various concentrations of Citric acid ranging from 1-50\% have been used. ${ }^{16,17}$ Yamaguchi et al (1996) ${ }^{18}$ compared the chelating and antibacterial properties of Citric acid and EDTA. They found citric acid to have better chelating and antibacterial properties than EDTA. Machado Silveiro et al (2004) ${ }^{19}$ also found 10\% Citric acid to be more effective than 17\% EDTA. Ali Reza Farhat et al $(2008)^{20}$ also found Citric acid to be a more effective irrigant than EDTA for removal the smear layer and for improving the apical seal.

However, Liolios et al in $1997^{21}$ reported better removal of smear layer by commercial EDTA preparations than $50 \%$ citric acid. Yamada et al $(1983)^{17}$ also found the combination of EDTA with $\mathrm{NaOCl}$ to produce cleaner canals than Citric acid in combination with $\mathrm{NaOCl}$. Certain studies indicate no significant difference in smear layer removal efficacy of, either of the chelating agent used. Dilenards et al $(2000)^{22}$ and Scelza et al $(2003)^{23}$ reported a minor or no difference in smear layer removal with Citric acid and 15\% EDTA. Violeta et al (2005) ${ }^{24}$ found no statistically significant difference in the cleaning efficacy of $17 \%$ EDTA and $25 \%$ citric acid.
Chelating agents are used in Endodontics to soften dentin, facilitate access to the entire root canal length and to remove the smear layer formed during root canal instrumentation. EDTA was the first chelating agent introduced by Nygaard- Ostby in 1957. Although the efficacy of EDTA in removing the smear layer has been proven, different mixtures, concentrations and volumes of irrigation are often used. Disadvantage associated with EDTA solutions at concentrations similar to those used in Endodontics is cytotoxicity, whereas Citric acid shows relatively lower toxicity. ${ }^{25}$ In Operative Dentistry, Citric acid has been proposed as a mild etchant, for dental hard tissue, particularly for dentinal conditioning and enhanced smear layer and plug removal..$^{15,16,17,18}$ In Endodontic research, substitution of EDTA with an aqueous Citric acid solution has been advocated by Yamaguchi et al in $1996^{18}$. This acid is known to cause demineralization of tooth structure. This phenomenon could be attributed to high acidity of citric acid, excessive etching of the dentinal matrix. This low $\mathrm{pH}$ may be quoted as a reason for increased efficiency of Citric acid over EDTA in the removal of smear layer and areas of disintegration of peritubular and intratubular dentin, with a substantial enlargement of the middle diameter of the tubules. ${ }^{23}$

Another important finding of our study supports a well documented finding that coronal third of the root canal is the cleanest followed by the middle and the apical third ${ }^{5,12,13,14}$ owing to the fact that this part of the root canal is easiest to instrument. It also receives the maximum irrigant volume and the larger taper in this part adds to the flushing out of the irrigant during the chemomechanical preparation of the root canal, rendering it cleaner than the middle and the apical third. Irrigation with $5.25 \% \mathrm{NaOCl}$ and $25 \%$ citric acid was again found to be superior in this region than that of $5.25 \% \mathrm{NaOCl}$ and $17 \%$ EDTA due to the reasons mentioned above.

The results of the present study clearly demonstrate that the simple preparation of citric acid solutions, their low cost, good chemical stability and their effectiveness even with short application times, is suitable for clinical use.

\section{CONCLUSION}

On the basis of the results obtained in this study it can be concluded that a larger taper (6\%) instrument 
produces cleaner canal than a smaller taper $(2 \%$ or $4 \%)$ instrument. $25 \%$ Citric acid in combination with 5.25\% $\mathrm{NaOCl}$ produces cleaner canal than $17 \%$ EDTA in combination with $\mathrm{NaOCl}$. Moreover the combination of larger taper $(6 \%)$ instrument and the irrigation regime of $25 \%$ Citric Acid with $5.25 \% \mathrm{NaOCl}$ tends to remove more smear layer in the coronal third of the canal than middle and the apical third.

\section{REFERENCES}

1. Cohen S. Pathways of Pulp. Elsevier Publications. X edition. p. 288.

2. Brannstrom M 1984. Communication between the oral cavity and the dental pulp associated with dental treatment. Opr. Dent 1984; 9:57-68.

3. Economides N, Liolise E, KoloKuris L, Beltes. Long-Term Evaluation of the Influence of Smear Layer Removal on the Sealing Ability of Different Sealers. J Endod 1999;25:123-25.

4. Heredia MP, Luque CMF, Rodriguez HPG. The Effectiveness of Different Acid Irrigating Solutions in Root Canal Cleaning After Hand and Rotary Instrumentation. J Endod 2006;32:993-997.

5. Arvaniti IS, Khabbaz MG. Influence of Root Canal Taper on Its Cleanliness: A Scanning Electron Microscopic Study. J Endod 2011;37:871-874

6. Yamada RS, Armas A, Goldman M. Lin P. A Scanning Electron Microscopic Comparison of a High Volume Final Flush with Several Irrigating Solutions: Part 3. J Endod 1983:9:137-142.

7. Loizides AL, Kakavetsos VD, Tzanetakis GN, Kontakiotis EG, and Eliadcs G. A Comparativc Study of the Effects of Two Nickel-Titanium Preparation Techniques on Root Canal Geometry Assessed by Microcomputed Tomography. J Endod 2007;33:1455-59.

8. Pentelescu C., Colceriu L., Culic C., Pastrav 0., Chisnoiu R., Muresanu L., Nicola C. And Trif M. A Study of Root Canal Preparation with Two Rotary Instruments. Joint Meeting of the Continental European, Israeli and Scandinavian Divisions of the IADR September 10-12, 2009.

9. Wandelt S, Wurzenkanale . Efficacy of greater taper files on root canal cleanliness. Deutsch Endod J.1965;20:621-6.

10. Lee SJ, Waselink PR. The efficacy of ultrasonic irrigation to remove artificially placed debris from different sized simulated plastic root canals. Int Endod 2004;30:110-2.
11. Van der Sluis LWM, Wasselink PR. The efficacy of ultrasonic irrigation to remove artificially placed debris from human root canals prepared using instruments of different taper. Int Endod J2005;38:764-5.

12. Usman N, Baumgartner JC, Marshall JG. Influence of instrument size on root canal debridement. J Endod 2004;30:110-2.

13. Haikel Y, Allemann C. Effectiveness of Four Methods for Preparing Root Canals: A Scanning Electron Microscopic Evaluation. J Endod 1988; 14:340-45

14. Buchanan LS. The standardized taper root canal preparation; part I. Int Endod J 2004;30:110-2.

15. Haapsalo M, Endal U, Zandi H, Coil J.Eradication of endodontic infection by instrumentation and irrigation solution. Endod Topics 2005;10:72-102.

16. Loel DA. Use of acid cleanser in endodontic therapy.J Am Dent Assoc 1975;90:148-151.

17. Dakin HD. On the basis of certain antiseptic substances in the treatment of infected wounds. Br Med J318, 1915.

18. Yamaguchi M, Yoshida K, Suzuki R, Nakamura H. Root canal irrigation with citric acid solution.J Endod . 1996;22:27-29.

19. Silveiro M,Lopez G, Rodriguez G. Decalcification of dentin by citric acid, EDTA, and sodium citrate. Int Endod J2004;37:365-369.

20. Klyn SL, Kirkpatrick TC, Rutledge RE. In Vitro Comparisons of Debris Removal of the EndoActivator TM System, the F FiIeTM, Ultrasonic Irrigation, and $\mathrm{NaOCI}$ Irrigation Alone after Hand-rotary Instrumentation in Human Mandibular Molars. J Endod 2010;36:1367-71.

21. Liolios E,Economides N, Parissis M. The effectiveness of three irrigating solutions on root canal cleaning after hand and mechanical preparation. Int Endod J2000;30:51-7.

22. Lenarda DR, Cadenaro M, Sbaizero O.Effectiveness of $1 \mathrm{~mol}$ $/ \mathrm{L}$ citric acid and 15\% EDTA irrigation on smear layer removal. Int Endod J 2000;33:46-52.

23. Scelza MFZ, Texwiria AM, Scelza P. Decalcifying effect of EDTA - T, 10\%citric acid on root canal dentin. Int Endod J 2003;95:235-39.

24. Municy PJ, Goode GG. Comparison of Passive Ultrasonic Debridement Between Fluted and Nonfluted Instruments in Root Canals. J Endod 2007;33:578-80.

25. Di Lenarda, Cernaz A, Sbaizerro O. Effects of citric acid irrigation on smear layer removal and dentinal microhardness. European Society of Endodontology. 1997;20:46-49. 